\title{
Synergistic Effect of Arecoline in Combination with Doxorubicin on HeLa Cervical Cancer Cells
}

\author{
Astrid Ayu Maruti, Fikri Amalia, and Edy Meiyanto* \\ Cancer Chemoprevention Research Center Faculty of Pharmacy, Universitas Gadjah Mada, Yogyakarta, Indonesia
}

\begin{abstract}
Arecoline, the main alcaloid of Areca cathecu $L$ has been proven to posses cytotoxic activity against various cancer cell lines. The research conducted to examine the cytotoxic activity of arecoline alone and its combination with doxorubicin against HeLa cervical cancer cell line. Single treatment of arecoline in various concentration on HeLa cancer cell were done followed by the combinational treatment with doxorubicin. The cell viability as the parameter of cytotoxicity was measured using MTT (3-(4,5-dimetiltiazol-2-il)-2,5difeniltetrazolium bromide) assay. The apoptotic effect was examined by double staining assay using etidium bromide-acridin orange. Arecoline did not show potent cytotoxicity effect against HeLa since the value of $I_{50}$ is $462 \mu \mathrm{M}$. The combinational treatment of arecoline and doxorubicin showed synergicity with the optimum $\mathrm{Cl}$ value is 0.48 given by the treatment of $30 \mathrm{mM}$ arecoline combined with $125 \mathrm{nM}$ doxorubicin. The result of this study shows that arecoline has potential to be proposed as co-chemotherapeutic agent for cervical cancer. However, further study on its molecular mechanism needs to be conducted.
\end{abstract}

Keywords: cinnamon essential oil, doxorubicin, T47D cells, combination cytotoxicity

\section{INTRODUCTION}

Cervical cancer is the second most common cancer found in women all over the world. International Agency for Research in Cancer reported that in 2008 there are 532.232 cases of cervical cancer in 100 million women. One of chemotherapeutic agents that commonly used is doxorubicin. Unfortunately, a recent study showed that high dose of doxorubicin may cause cardiotoxicity in human (Gunawan, 2007). It is possible to lower the dose of doxorubicin for therapy but it will also lessen the activity (Wattanapitayakul, et al., 2005). Therefore, it is needed to develop a new approach of treatment such as using cochemotherapeutic agents.

Arecoline $\left(\mathrm{C}_{8} \mathrm{H}_{13} \mathrm{NO}_{2}\right)$ is an alkaloid compound found in pinang fruit (Areca catechu L.). Some in vitro study showed that arecolin have cytotoxicity towards oral and liver cancer cells, and induce apoptosis in basal cancer cells (Chang, et al., 2001; Cheng, et al., 2010). Arecoline is a promising compound to be used as co-chemotherapeutic agent of doxorubicin. Previous study showed that arecoline is able to induce cell cycle arrest in KB cell line (Chang, et al., 2001). It is recently reported by Cheng, et $a l$ in 2010 that arecoline may induce apotosis in human hepatoma HA22T/VGH cell line through the by supressing the production of $\mathrm{Bcl}-\mathrm{XL}$ and $\mathrm{Bcl}-2$ protein, increasing $\mathrm{p} 53$ production, and inducing the release of cytochrom c from mitochondrial membrane.

HeLa cells are known to express 2 kinds of oncogenes, E6 and E7. E6 bounds with p53 fosforilated protein meanwhile the E7 bounds with $\mathrm{pRb}$ protein (Jansen, et al., 2006). The bonding of p53 protein by the E6 causing the increase of protein's degradation rate. Arecoline reported to have ability in increasing the p53 expression and the expression of the gen that encode the $\mathrm{p} 21^{\mathrm{WAF} 1}$ (Chou, et al., 2009). Besides, the arecoline can alo induce the expression of Bax, the proapoptotic protein and inhibits the Bcl-2 which is antiapoptosis protein on hepatoma cells HA22T/VGH (Cheng, et al., 2010).

\footnotetext{
*Corresponding author e-mail: meiyan_e@ugm.ac.id
} 


\section{MATERIALS AND METHODS}

\section{Tested Compounds}

The main compounds used in this study was Arecoline Hydrobromide (VETRANAL ${ }^{\circledR}$ Sigma Aldrich Number of Catalog 46063) obtained from Warista Yogyakarta. The chemotherapy agent doxorubicin in the form of injection solution in the concentration of 50 $\mathrm{mg} / 25 \mathrm{~mL}$ (Kalbe Farma) were obtained from Dr. Sardjito Hospital Yogyakarta.

\section{Cell Culture}

HeLa cells were the collection of Cancer Chemoprevention Research Center, Faculty of Pharmacy, Universitas Gadjah Mada. Cells were cultured in the DMEM culture media 1640 (Gibco) containing $10 \%$ v/v Fetal Bovine Serum (FBS) (Gibco) and penisillinstreptomycin $100 \mu \mathrm{g} / \mathrm{mL}$ (Gibco) and incubated in $\mathrm{CO}_{2}$ incubator (Herceus) in the $37^{\circ} \mathrm{C}$ themperature and $5 \% \mathrm{CO}_{2}$.

\section{Cytotoxic Assay}

The cytotoxicity assay were done by MTT assay. HeLa cells were distributed in to 96 well plates (Nunc) with 5000 in cells each well. The cells were incubated for 24 hours in the $\mathrm{CO}_{2}$ incubator (Herceus) with arecolin both for the single and combinational cytotoxic assay. DMSO was used as the solvent. In the end of the incubation time, each well were added by $100 \mu \mathrm{L}$ MTT reagent (Sigma) in the DMEM culture media (Gibco). The plate were incubated for 4 hours in $37^{\circ} \mathrm{C}$ themperature until the formazan crystal were formed (to observed the formazan crystal were done under the inverted microscope (Olympus $\mathrm{CH}-2)$ ). After 4 hours of incubation the reaction were stopped by adding the SDS $10 \%$ as stopper reagent as many as $100 \mu \mathrm{L}$ in each well and was incubated for 24 hours in the room themperature.

This proccess provide the color change in the cells' media. The yellow colour would turn into purple because of the dehidrogenase enzim activity in the living cells which breaks the tetrazolium rings from MTT reagents in to formazan crystal. The intensity if absorbance of the formazan crystal were obtained by the ELISA reader Bio-Rad microplate reader Benchmark serial no. 11565, Japan) with 595 nm wavelenght.

\section{Apoptosis Induction}

The confluent culture of HeLa cells wre harvested and distributed in the concentration of $5 \times 10^{4}$ cells/well on the coverslips (Nunc) and added by $1000 \mu \mathrm{L}$ of culture media. Cells were incubated for 24 hours in the $\mathrm{CO}_{2}$ incubator so that cells were adapted and in normal condition. Cells were given the treatment as control cells, $1 /{ }_{16} \mathrm{IC}_{50}$ arecoline, $3 / 8 \quad \mathrm{IC}_{50}$ arecoline, $1 / 8 \quad \mathrm{IC}_{50}$ doxorubicin, combination of $1 / 16$ IC $\mathrm{IC}_{50}$ arecoline with $1 / 8 \mathrm{IC}_{50}$ doxorubicin, and combination of $3 / 8 \quad \mathrm{IC}_{50}$ arecoline with $1 / 8 \quad \mathrm{IC}_{50}$ doxorubicin, and then incubated for 24 hours. In the end of incubation, the DMEM culture media were washed by PBS and the cover slips were lifted and placed on the object glass and were dropped by etidium bromide-acridine orange as many as $10 \mu \mathrm{L}$. The observation of cells morphology were done under the fluorescence microscope (Zeiss MC 80).

\section{Data Analysis}

Cytotoxicity Assay

The absorbation of each well were converted in to the percent of cell viability. The percent of cell viability were calculated by the formula:

$$
\% \text { cell viability }=\frac{\text { abs of drug treated sample }}{\text { abs of control }} \times 100 \%
$$

Based on the regretion equation were counted the $\mathrm{IC}_{50}$ concentration (the concentration causing death fo $50 \%$ of population) so that can be determined the cytotoxic potency (Doyle and Griffiths, 2000).

\section{Combinational Cytotoxicity Assay.}

Combinational treatment was evaluated by calculating Combination Index (CI) value (Reynolds and Maurer, 2005), which has the formula as follows:

$$
\mathrm{CI}=\mathrm{D} 1 / \mathrm{D} x 1+\mathrm{D} 2 / \mathrm{Dx} 2
$$

D1 and D2 represent concentrations used in combinational treatment, while Dx1 and Dx2 are single treatment concentration giving same response as D1 and D2, respectively. CI value acquired will allow the evaluation of Arecoline's potency in combinatorial treatment with doxorubicin on HeLa cells. Interpretation was done based on the classification listed in Table 1. 
Table I. Interpretation of $\mathrm{Cl}$ value representing potency of combinational application

\begin{tabular}{|c|c|c|c|}
\hline $\mathbf{C l}$ & Interpretation & $\mathbf{C I}$ & Interpretation \\
\hline$<0.1$ & Very strong synergist & $0.9-1.1$ & Closely additive \\
\hline $0.1-0.3$ & Strongly synergist & $1.1-1.45$ & Middle antagonist \\
\hline $0.3-0.7$ & Synergist & I.45-3.3 & Antagonist \\
\hline $0.7-0.9$ & Middle synergist & $>3.3$ & Strongly antagonist \\
\hline
\end{tabular}

\section{Apoptosis Assay Analysis}

The green fluorescence showed the living cells. The early stage of apoptosis will undergo the chromatin condensation and will be green in colour. Meanwhile the late apoptotsis cells will be broken in to the small parts and become orange in colour (Renvoize, et al., 1998).

\section{RESULTS AND DISCUSSION}

\section{Effect of Arecoline on HeLa Cells Growth}

The cytotoxic assay was done to determine the cytotoxic potency of Arecoline as tested compound. The potency was expressed in the parameter of $\mathrm{IC}_{50}$. The treatment of arecoline in the concentration of $1 \mu \mathrm{M}, 10 \mu \mathrm{M}$, $50 \mu \mathrm{M}, 100 \mu \mathrm{M}, 250 \mu \mathrm{M}, 500 \mu \mathrm{M}, 750 \mu \mathrm{M}$, and $1000 \mu \mathrm{M}$ on HeLa cells caused HeLa cells growth decreased as the concentration of compound increased. Based on this study, the $\mathrm{IC}_{50}$ of Arecoline on HeLa cells is $462 \mu \mathrm{g} / \mathrm{mL}$ (Fig. 1). The observation of $\mathrm{HeLa}$ cells morphology after the treatment of arecoline showed the cells death (cells become round in shape and deattached from the well plate) increased as the concentration of arecolin increased (Fig. 2)

This $\mathrm{IC}_{50}$ value of arecoline on $\mathrm{HeLa}$ cells showed that arecoline do not cause the strong cytotoxic activity on HeLa cells, compared with the other alkaloid such as scimmiamianin, flindercin, and haplopine (Jansen, et al., 2006). Although the cytotoxic effect of this compound is not too strong, it is still possible for arecoline to be used as cochemotherapy agent with doxorubicin.

Doxorubicin is known to have $\mathrm{IC}_{50}$ value $1000 \mathrm{nM}$ on HeLa cells (Larasati, 2010). This showed that HeLa cells is not too sensitive with the treatment of doxorubicin. The $\mathrm{IC}_{50}$ value on $\mathrm{HeLa}$ cells is higher than the $\mathrm{IC}_{50}$ value of doxorubicin in other cancer cell such as T47D (43 nM) (Larasati, 2010; Jenie and Meiyanto, 2006). This could be caused by the resistence of doxorubicin on HeLa cells by the antiapoptotic protein in $\mathrm{HeLa}$ cells, ARC (apoptosis repressor with caspase recruitment domain) and efflux mechanism of doxorubicin from HeLa cells (Wang, et al., 2009, Bravo-Cuellar, et al., 2010). Therefore, the observation of combinational cytotoxicity of these two compound is needed to be done.

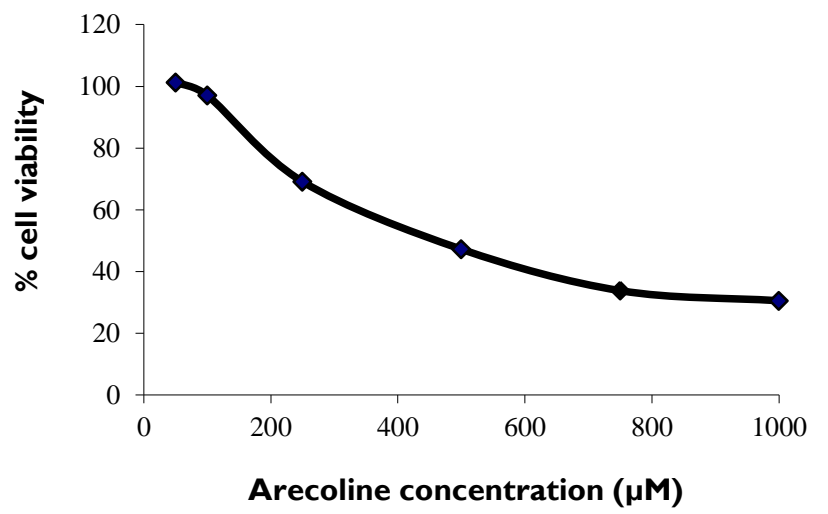

Figure I. The effect arecoline on the growth of HeLa cells. As many as 5000 cells/well HeLa cells were incubated in the 96 well plates, and given the treatment of arecoline in the range concentration I-1000 $\mu \mathrm{M}$. 


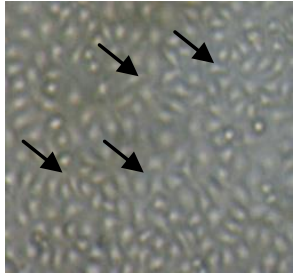

(A)

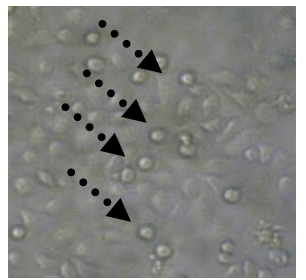

(E)

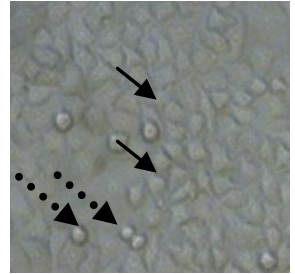

(B)

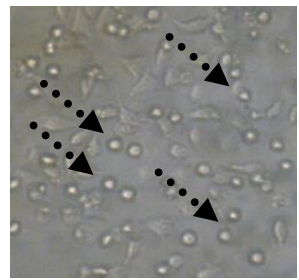

(F)

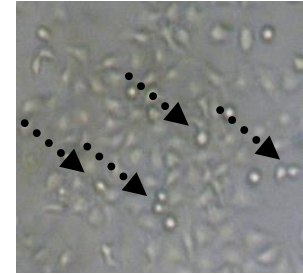

(C)

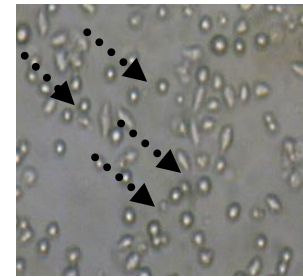

(G)

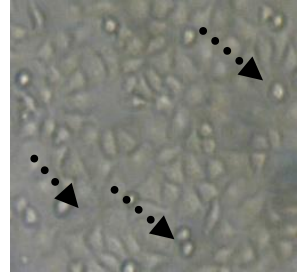

(D)

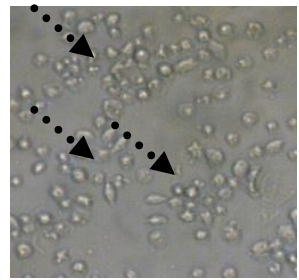

(H)

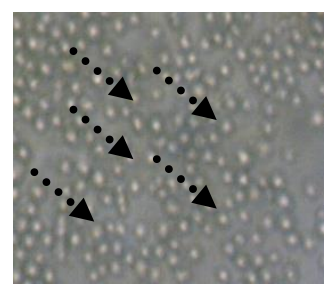

(I)

Figure 2. The effects of single treatment of arecoline on the HeLa cells morphology. As many as 5000 cells/well were incubated in the 96 well plates. The observation of cell's morphology were done by using inverted microscope with 100x magnification. The figure showed control cells $(A)$, cells treated by arecoline I $\mu \mathrm{M}$ (B), $10 \mu \mathrm{M}(\mathrm{C}), 50 \mu \mathrm{M}(\mathrm{D}), 100 \mu \mathrm{M}(\mathrm{E}), 250 \mu \mathrm{M}(\mathrm{F}), 500 \mu \mathrm{M}(\mathrm{G}), 750 \mu \mathrm{M}(\mathrm{H})$, and $1000 \mu \mathrm{M}(\mathrm{I})$. The arrow $\longrightarrow$ showed viable cells, meanwhile $\ldots \ldots \rightarrow$ showed death cells.

\section{Effect of Arecoline Combined with Doxorubicin on HeLa Cells Growth}

Combination assay was done by combining $1 / 16 \mathrm{IC}_{50}, 1 / 8 \mathrm{IC}_{50}, 1 / 4 \mathrm{IC}_{50}, 3 / 8 \mathrm{IC}_{50}$ of Arecoline with $1 / 16 \quad \mathrm{IC}_{50}, 1 / 8 \quad \mathrm{IC}_{50}, 1 / 4$ $\mathrm{IC}_{50}, 3 / 8 \mathrm{IC}_{50}$ of doxorubicin. The cells viability were quantified by combination index (CI). Table II showed that the optimum IC value were obtained by combining $1 / 16 \mathrm{IC}_{50}$ arecoline with $1 / 8 \mathrm{IC}_{50}$ doxorubicin with IC value 0.48 , and the combination of $3 / 8 \mathrm{IC}_{50}$ arecoline with $1 / 8 \mathrm{IC}_{50}$ doxorubicin with $\mathrm{CI}$ value 0.52 . The synergistic effect of doxorubicin in the combination with Arecoline probably through the apoptosis induction mechanism so taht the observation of this mechanism should be done.

Table 2. Combination Index combination of CEO and doxorubicin

\begin{tabular}{ccccc}
\hline Arecoline (jg) & \multicolumn{4}{c}{ Doxorubicin (nM) } \\
\cline { 2 - 5 } & $\mathbf{6 2 . 5}$ & $\mathbf{1 2 5}$ & $\mathbf{2 5 0}$ & $\mathbf{3 7 5}$ \\
\hline 30 & 0.76 & 0.48 & 0.72 & 0.88 \\
60 & 0.79 & 0.84 & 1.17 & 1.83 \\
120 & 0.62 & 0.81 & 1.72 & 1.77 \\
175 & 0.56 & 0.52 & 1.06 & 1.39 \\
\hline
\end{tabular}


Treatment with combination of CEO $37.5 \mu \mathrm{g} / \mathrm{mL}$ and doxorubicin $1.25 \mu \mathrm{M}$ reduced cell viability significantly different with single treatment of each agent. While combination treatment with lower concentration of CEO $(9.375 \mu \mathrm{g} / \mathrm{mL})$ and doxorubicin did not reduce cell viability significantly compound to the doxorubicin solely (Fig. 2).

\section{Effect of CEO and Doxorubicin on Apoptosis Induction}

Double staining using ethidium bromide and acridin orange was used to observe the induction of apoptosis. Single treatment of CEO $37.5 \mu \mathrm{g} / \mathrm{mL}$ and doxorubicin $5 \mu \mathrm{M}$ induced apoptosis of T47D cells. Apoptotic induction was indicated by orange fluorescent in the nucleus (Fig. 3). The result showed that combination treatment of CEO and doxorubin increased the number of cells containing red/orange fluorescent. These data indicated that the combination of CEO and doxorubicin increased the incidence of apoptosis.

The therapy of cervical cancer by doxorubicin needs high dose of treatment and usually cause the side effects such as nausea, hair loss, and cardiotoxicity. The synergistic effect of arecolin in the combination with doxorubicin can reduce the dose of doxorubicin to obtain the same effect. As the dose is reduced, the side effect of doxorubicin can be reduced. Doxorubicin can induce the DNA strand break so that induce apoptosis. (Drummond, 2007). Arecoline also reported to induce the DNA strand break in mamalia cells (Chang, et al., 2001). The synergistic effect of these two compounds are probably by the DNA strand break mechanism.

\section{The effect of arecoline and combination with doxorubicin in the apoptosis induction}

The determination of the induction of apoptosis by the combination of Arecoline with doxorubicin in HeLa cells were done by apoptosis assay by double staining method. The result of this assay showed that the combination of arecoline and doxorubicin can induce the better apoptosis incidence than the single treatment of each compound. The apoptosis effect showed by the fluorescence of tge cells in to orang ecolour that caused by the decrease of membrane cells permeability. Some cells showed the nucleus fragmentation and the formation of apoptotic body (Fig. 4).

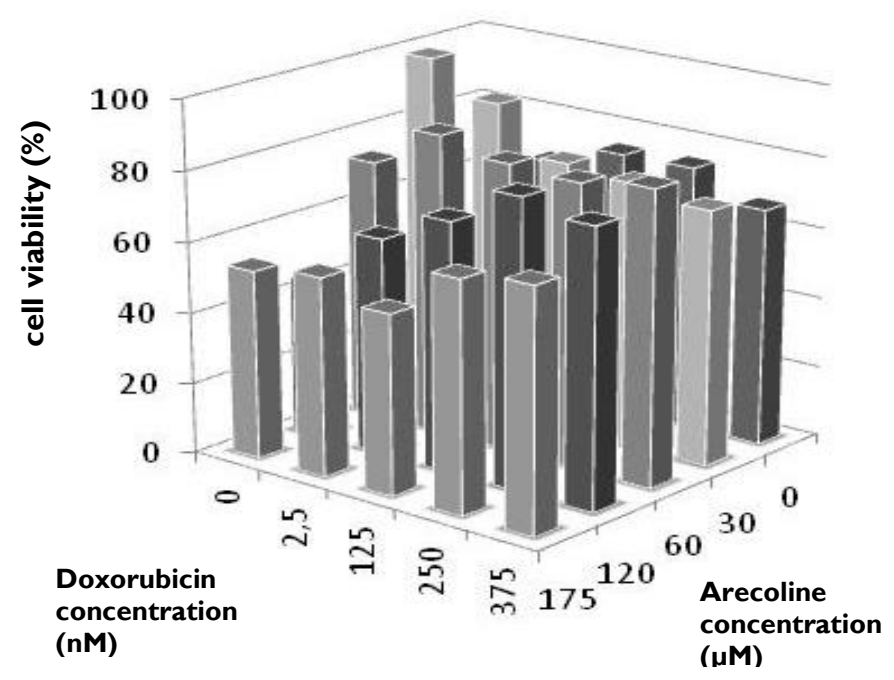

Figure 3. The effects of combination treatment of arecoline with doxorubicin on the HeLa cells viability. Cells were incubated for 24 hours and given the treatment of arecoline in combination with doxorubicin $1 / 16 I_{50}, 1 / 8, I C_{50}, 1 / 4 I_{50}$ and, $3 / 8, I_{50}$. The graph shows HeLa cells viability after the treatment $(p<0.05)$. 


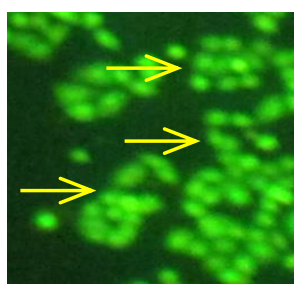

A

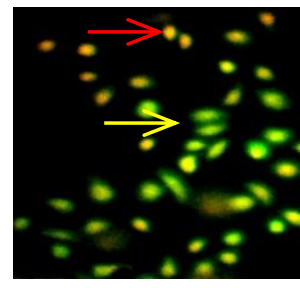

B

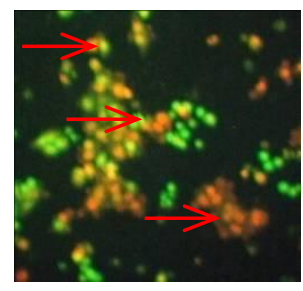

C

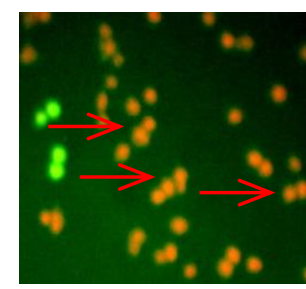

D

Figure 4. The effects of single and combination of arecoline and doxorubicin in the induction of apoptosis on HeLa cells. Control cells (A), Doxorubicin $125 \mathrm{nM}(\mathrm{B})$, Arecoline $175 \mu \mathrm{M}(\mathrm{C})$, and the combination of $175 \mu \mathrm{M}$ arecoline and $125 \mathrm{nM}$ doxorubicin. The yellow arrows $\longrightarrow$ show the viable cells which green in fluorescence, and the red arrows $\rightarrow$ show the death cells which orange in fluorescence.

The induction of apoptosis by arecoline on HeLa cells probably by the p53 dependent mechanism and physical mechanism such as anoikis. This study showed the cytotoxic activity of arecoline and the synergistic effect of arecoline in the combination with doxorubicin on HeLa cells. The further research is need to be done to explain the molecular mechanism that mediate the cytotoxic activity of arecoline on HeLa cells and the synergistic effect with doxorubicin.

\section{ACKNOWLEDGEMENT}

Our thanks to Cancer Chemoprevention Research Center (CCRC), which has funded this research.

\section{REFERENCES}

Bravo-Cuellar, A., Ortiz-Lazareno, P.C., LermaDiaz, J.M., Dominguez-Rodriguez, J.R., Jave-Suarez, L.F., Aguilar-Lemarroy, A., et al., 2010, Sensitization of Cervix Cancer Cells to Adriamycin by Pentoxifylline Induces an Increase in Apoptosis and Decrease Senescence, Mol. Cancer., 9, II 4.

Chang, M.C., Ho, Y.S., Lee, P.H., Chan, C.P., Lee, J.J., Hahn, L.J., et al., 200I, Areca Nut Extract and Arecoline Induced The Cell Cycle Arrest But Not Apoptosis of Cultured Oral KB Epithelial Cells: Association of Glutathione, reactive Oxygen Species and Mitochondrial Membrane Potential, Carcinogenesis, 22(9), I5271535.
Cheng, H.L., Shu, J.S., Huang, L.W., Hsieh, B.S., Hu, Y.C., Hung, T.C., et al., 20I0, Arecoline Induces HA22T/VGH Hepatoma Cells to Undergo AnoikisInvolvement of STAT3 and RhoA Activation, Mol. Cancer, 9, 126.

Chou, W.W., Guh, J.Y., Tsai, J.F., Hwang, C.C., Chiou, S.J. and Chuang, L.Y., 2009, Arecoline-Induced Phosphorylated p53 and P2IWAFI Protein Expression is Dependent on ATM/ATR and Phosphatidylinositol-3-kinase in Clone9 Cells, J. Cell Biochem., I07(3), 408417.

Doyle, A. and Griffiths, J.B., 2000, Cell and Tissue Culture for Medical Research, New York: John Willey and Sons Ltd.

Drummond, C., 2007, The Mechanism of Antitumour Activity of the DNA Binding Agent SN 28049, Thesis, University of Auckland, New Zealand.

Jansen, O., Akhmedjanova, V., Angenot, L., Balansard, G., Chariot, A., Ollivier, E., et al., 2006, Screening of 14 Alkaloids Isolated from Haplophyllum A. Juss. for Their Cytotoxic Properties, J. Ethnopharmacol., 105(I-2), 24I-245.

Jenie, R.I., Meiyanto, E. and Murwanti, R., 2006, Efek Antiangiogenik Ekstrak Etanolik Daun Sambung Nyawa (Gynura procumbens (Lour.) Merr.) pada Membran Korio Alantois (CAM) Embrio Ayam, Indones. J. Pharm., I 7(I), 50-55.

Larasati., Kusharyanti, I., Hermawan, A., Susidarti, R.A. and Meiyanto, E., 20II, Naringenin Enhances The Antitumor Effect of Doxorubicin on Hela Cervical Cancer Cell Through Cytotoxic 
Activity and Apoptosis Induction, Indones. J. Cancer Chemoprevent., 2(3), 325-333.

Renvoize, C., Biola, A., Pallardy, M. and Breard, J., 1998, Apoptosis: Identification of Dying Cells, Cell Biol. Toxicol., I4, III120.

Reynolds, C.P. and Maurer, B.J., 2005, Evaluating Response to Antineoplastic Drug Combinations in Tissue Culture
Models, Methods Mol. Med., I I0, I73183.

Wang, J.X., Li, Q. and Li, P.F., 2009, Apoptosis Repressor with Caspase Recruitment Domain Contributes to Chemotherapy Resistance by Abolishing Mitochondrial Fission Mediated by Dynamin-related ProteinI, Cancer Res., 69(2), 492-500. 